How to cite this article:

Nawang, N. I., Mohamed, A. M. T., \& Mustaffa, A. (2020). Online news portal in Malaysia - A revisit to the regulatory regime governing the media in the era of media convergence. UUM Journal of Legal Studies, 11(1), 117-142. https:// doi.org/10.32890/uumjls.11.1.2020.8263

\title{
ONLINE NEWS PORTALS IN MALAYSIA - A REVISIT OF THE REGULATORY REGIME GOVERNING THE MEDIA IN THE ERA OF MEDIA CONVERGENCE
}

\section{${ }^{1}$ Nazli Ismail Nawang, Abdul Majid Tahir Mohamed \& Aminuddin Mustaffa}

Faculty of Law and International Relations, Universiti Sultan Zainal Abidin (UniSZA), Malaysia

1Corresponding author: inazli@unisza.edu.my

Received: 2/1/2020 Revised: 11/1/2020 Accepted: 16/1/2020 Published: 31/1/2020

\begin{abstract}
Online news portals such as Malaysiakini, Malaysia Today and many others have been instrumental in providing alternative news and information to the Malaysian public. These portals are currently treated differently from print media as they need not procure a licence or permit before publishing online content. Conversely, print media proprietors are mandated by the Printing Presses and Publications Act 1984 to hold valid printing licences and publication permits before offering their services. Further, the presence of the no censorship guarantee of the Internet appears to render online news portals and other online publications to be free from legislative control. This is undesirable as there appears to be two different sets of regulatory frameworks for traditional media and new media. Hence, this paper will trace the historical development of online news portals in Malaysia, analyse the existing regulatory regime which govern print media and new media, and examine the potential application of these laws to regulate online news portals. By adopting a qualitative approach, the study employed a combination
\end{abstract}


of doctrinal and comparative analysis. A doctrinal analysis was adapted to explore the current regulatory framework in order to address the legal predicament faced by online news portals. Further, the study applied a comparative analysis method by examining current practices and experience in the United Kingdom (UK). For this reason, the study scrutinised relevant statutory provisions and other secondary sources comprising textbooks, academic journals, seminar papers, and other pertinent materials found in newspapers and/or reputable websites. In conclusion, it is submitted that the same set of laws and regulations should be applied to govern print media and online news portals here, similar to the practice adopted by the Independent Press Standards Organisation (IPSO) in the UK.

Keywords: Online news portals, regulatory framework, new media, traditional media.

\section{INTRODUCTION}

The technological convergence of the telecommunications, broadcasting, and computing industries into a single digital bitstream (Blackman, 1998) and the mounting popularity and growing availability of a vast array of new media services have been reported to significantly affect the distribution and consumption of news in Malaysia (Ahmad \& Buyong, 2017). These developments have resulted in the transposition of readership from traditional media to various types of online media services, in particular, online news portals and social media (Nain, 2018). In this regard, the Internet is currently preferred by the majority of the people in the country, in particular the young adults, as their primary source of news in comparison with the reportage or coverage by mainstream media (Freeman, 2013).

The latest Internet Users Survey (IUS), an annual survey effectuated by the Malaysian Communications and Multimedia Commission (MCMC), which was released on 11 January 2019 reported that 28.7 million people or 87.4 per cent of the total population of the country used the Internet in 2018 (MCMC, 2019). This figure is an increase from 24.5 million or 76.9 per cent in 2016 and 20.1 million or 66.6 per cent in 2014. To this end, it is contemplated that with the continual rise of Internet penetration and usage in Malaysia, the new media would continue to have a substantial consequence on the 
media landscape in the country. This trend is further supported by the Digital News Report 2019 by Reuters Institute for the Study of Journalism which showed that 86 per cent of Malaysians chose online and social networking sites as their source of latest information and news over established mainstream media (Newman, Fletcher, R., Kalogeropoulos, A., \& Nielsen, 2019).

Regarding the implications of new media services, George (2005) observed that these new media are instrumental in providing independent and alternative news compared to traditional media as the latter have been on numerous occasions, perceived to be partial and inclined towards the ruling government (Azlan, Rahim, Hassan Basri, \& Hasim , 2012). This situation is not surprising as traditional media have been subjected to strict regulatory control under the Printing Presses and Publications Act 1984 (PPA); owned by trusted confidants or close associates of the ruling parties in the government (Kim, 1998); and controlled via self-censorship by their chief editors and journalists (Halim \& Salim, 2005). The same proposition has also been adopted by Netto (2002), who asserted that media freedom in the country is constrained by restrictive laws, and media ownership and self-censorship are applied by chief editors and journalists of traditional media.

Despite claims that the government's pervasive reign over traditional media is primarily aimed at maintaining national security and political survivability (Sani, 2005), it is submitted that the aforesaid mechanisms that are embraced to regulate traditional media seem to be inappropriate and no longer feasible to be extended and applied to new media. Ahmad and Buyong (2017) observed that robust control by the government over traditional media appears to be an indirect catalyst for the people's support and leaning towards new media platforms, particularly independent news portals like Malaysiakini, Malaysia Today, Free Malaysia Today, and many others. Such a scenario is arguably anticipated because people have been seeking alternative news and balanced coverage, which are hardly found or even reported at all in traditional media. Furthermore, web-based channels have the unique attributes of being mostly cost-free, easily accessible, flexible, and user-friendly (Tiung, Meri, Nayan, \& Othman, 2016). Further, Mustaffa, Ibrahim, Samani and Rahim (2010) discovered that among the main attractions of the new media is that their news and reportages are frequently updated as compared to the traditional media. 
Apart from that, operators of online news portals appear to have taken advantage of the no censorship guarantee of the Internet, which is contained in the MSC Malaysia Bill of Guarantees (BoGs) ${ }^{4}$ and the Communications and Multimedia Act 1998 (CMA). ${ }^{5}$ Though there is arguably greater online freedom for Internet users in the country (Ismail Nawang, 2014), the no censorship promise of the Internet does not render online communication to be beyond any shackles of law. Post-publication laws including the CMA, the Penal Code, the Defamation Act 1957, the Sedition Act 1948, the Official Secrets Act 1972 and many others on content regulation may still be applied to online publications (Halim \& Salim, 2005). The application of these statutes could be clearly observed in a few judicial decisions that have been brought against Internet users. Thus, it would be incorrect to hold that the Internet is a legal vacuum based merely on the no censorship guarantee of the Internet.

Nonetheless, online news portals are currently not subjected to the pre-publication laws of the PPA that specifically require new media operators or owners to secure a printing licence or a publication permit. The present situation is undesirable as there appears to be two different sets of regulatory frameworks governing the publication and distribution of news: one for traditional print media and the other legal regime for new media services including online news portals. Apart from that, there are legitimate apprehensions about the trustworthiness and reliability of stories in online news portals as they can simply be published without much scrutiny and proper verification since online news portals could conceivably lack editorial checking and gatekeeping.

To make matters worse, online news portals on certain incidents have appeared to ignite tensions among the multiracial population in the country by highlighting controversial issues that could lead to

4 The Bill of Guarantees (BoGs) refers to a set of ten incentives, rights, and privileges that are accorded to the MSC Malaysia Status Companies by the government of Malaysia. BoG 7 guarantees that the government will "ensure no censorship of the Internet". For further details on the BOGs, see $<$ https://www.mida.gov.my/env3/uploads/IncentivesCompilation/MDEC/2013/AppII.pdf> last accessed on 4 March 2020.

5 Section 3(3) of the CMA provides that "Nothing in this Act shall be construed as permitting the censorship of the Internet". 
unease among the people (Alivi, Ghazali, Tamam, \& Osman, 2018). Due to several critical issues associated with online news portals, the former Communications and Multimedia Minister, Dato' Seri Dr Salleh Said Keruak, reported that the government may in the future require online news portals to register so as to protect national interests (Carvalho, Sivanandam, \& Ghazali, 2015). Even though the proposal did not materialise as it was made under the previous government of the National Front (Barisan Nasional), it is perhaps still relevant to revisit and analyse the existing regulatory framework governing traditional and new media, particularly the online news portals in Malaysia.

In a nutshell, online news portals or other new media services are currently being preferred by the public over traditional print and broadcast media. Nonetheless, unlike print media which are regulated by the PPA, online news portals are currently not subjected to any pre-publication rules. Further, the no censorship of the Internet policy seems to accord greater freedom to Malaysians in cyberspace. This position is clearly unacceptable as there appears to be different treatment for offline and online media, and the latter may potentially be exploited to disseminate illegal and harmful content to the public at large.

\section{METHODOLOGY}

This research is qualitative in nature, and it adopts a purely legal research and doctrinal approach. It has analysed two primary legislation, namely the PPA, which is the existing laws that govern traditional print media; and the CMA, which is a specific statute that has been exclusively enacted to regulate the communications and multimedia industries, including the new media. The study has also examined relevant subsidiary legislation relating to the licensing of print media and exemption of Internet content applications services from the licensing requirements under the CMA. Apart from primary sources, textbooks, journal articles, seminar papers, and reputable websites, regarded as secondary sources, have also been referred to for this research. The data collected in this research are mainly published data, which have been critically analysed to attain the four primary objectives of this study, namely to trace the historical 
development of online news portals in Malaysia, to examine the existing legal framework governing traditional print and new media, to investigate the potential application of the present rules and regulations on online news portals, and to propose recommendations to issues surrounding the governance of online news portals.

This paper has also conducted a comparative study on the practices in the United Kingdom (UK) in the hope that the position in the UK can be used as a useful reference in exploring possible alternative solutions to the issues raised in this paper. This contention is in line with the argument by Manning (1983) that a comparative approach can be called on to evade oversights or errors since past experiences and approaches in other countries would be helpful in deciding and proposing solutions to any uncertainties. Further, Zweigert and Kötz (1987) observed that in any comparative analysis, the author needs to "first lay out the essentials of the relevant foreign law and then use this material as a basis for critical comparison, ending up with a conclusion about the proper policy for the law to adopt, which may involve a reinterpretation of his own system."

\section{HISTORICAL DEVELOPMENT OF ONLINE NEWS PORTALS}

The Reuters Institute Digital News Report 2018 reported that online news portals, including social media, have incessantly been the preferred medium for news. In the last three years (2017-2019), it was discovered that 87 per cent of those polled among the Malaysian sample had referred to online news sources in 2019, a steady increase by one point from 2017. Meanwhile, the popularity of print media as news sources had distinctly decreased from 45 per cent in 2017 to only 37 per cent in 2019 (Newman et al., 2019). Nain (2018) alleged that the changing trend of the media landscape from print media to online platforms was primarily attributed to the rising popularity and increasing availability of online news portals in the country. It was further alleged that print media had become less popular among Malaysians because their owners were openly aligned to and strongly supportive of the ruling government.

It is nonetheless not unexpected that print media in the country have been highly appreciative of the government, as the survival of their business operations and the careers of their reporters are primarily 
dependent on the permits and licences which are exclusively controlled by the Minister of Home Affairs according to the provisions of the PPA. A few past instances may illustrate this point, including the suspension of the Asian Wall Street Journal for three months in 1986 for publishing news which was allegedly detrimental to the image of the government and the immediate expulsion of its two foreign journalists from the country (AP News, 1986). Apart from foreign publications, the local newspapers had also faced the wrath of the government when the publishing permits of The Star, Sin Chew Jit Poh, and Watan were revoked in 1987 (Shukry, 2015). Such causality will never affect the entirely web-based publications, including online news portals, as they have never been made subject to the PPA. Consequently, it is noteworthy to trace the historical development of online news portals in the country.

The origin of online news portals in Malaysia started when The Star, one of the mainstream print media that is published by The Star Publications, introduced an online news portal called the Star Online in 1995. Two years later, other established traditional print media companies jumped on the bandwagon with the launch of Utusan Online, Berita Harian Online, and the New Straits Times Online (Kasim \& Mohd Sani, 2016). Apart from these mainstream media institutions, political parties and alternative media sites have also developed their own news websites, including Harakah Daily, Keadilan Daily, Malaysiakini, the Malaysian Insider, and many others.

By the early 2000s, several local online news portals had been established in the country. Chung, Kim and Kim (2010) classified these news portals into three categories based on their characteristics, namely, (1) mainstream news portals that replicate printed newspapers such as the Star Online, Berita Harian Online, and the New Straits Times Online; (2) independent news portals that produce and distribute news only on their online websites, such as Malaysiakini and Malaysia Today, among others; and (3) index news portals which refer to online search engines or Internet news services portals, such as Yahoo! News, which provides a collection of news content of other online newspapers.

Even though traditional print media organisations are the actual pioneers of the venture into online news portals; it is Malaysiakini, an independent news portal that has continuously been gaining 
the most acceptance and pervasive popularity among netizens in the country. Malaysiakini marked its entrance into the local media scene just before the 10th General Election in 1999, and captured the attention of the people as the first independent online news portal in the country (George, 2006). Malaysiakini's foray into online news reporting was indeed timely as the public were at that time looking for neutral and unbiased news as an alternative to traditional mainstream media. This is because mainstream media due to strict governmental control, have become the mouthpiece of the government, while any political dissent and public condemnations against the government are deliberately contained (Nain, 2000). Over the past 20 years, the popularity of Malaysiakini has continued to grow and spawned the emergence of other independent news portals such as Malaysian Insider, the Malaysian Insight and many others (Chinnasamy, 2018).

Regarding the readership and usage of online news portals, Reuters Digital News Report indicated that Malaysiakini continued to rank first among online news portals in Malaysia for two consecutive years in 2018 and 2019 with the same score of 44 per cent of weekly usage by users (Newman et al., 2019). The same reports also disclosed that The Star Online, Astro Awani Online, Berita Harian Online, and other mainstream news portals were trailing Malaysiakini (Newman et al., 2019). Perhaps, this was because these online news outlets were more often than not, the digital footprints of traditional print and broadcast media (Russo, 2006). In addition, it was claimed that Malaysiakini had maintained its reputation as the provider of independent and trustworthy news because the majority of the people, especially the younger generation, preferred impartial and non-partisan news coverage (Newman et al., 2019).

Despite the increasing support and broad acceptance of online news portals, Erlindson (1995) claimed that in general, online newspapers will not replace print media. On the same note, it was observed that online news portals in Malaysia complemented the role of print media (Ariffin \& Jaafar, 2009). Nonetheless, journalists of these online news portals, in particular Malaysiakini, have not been treated equally as their counterparts from the mainstream media as they have been regarded as not having an officially recognised status as journalists (Tong, 2004). Therefore, it is crucial to analyse the provisions of the PPA, which has been primarily legislated to supervise and control print media, in order to determine whether 
these online news portals will be subjected to the same regulatory regime that has been applied to traditional print media since Merdeka Day.

\section{THE PRINTING PRESSES AND PUBLICATIONS ACT 1984 (PPA)}

The origins of the PPA can be traced back to the consolidation of the two previous statutes governing print media in Malaysia, namely, the Printing Presses Act 1948 (Act 58) and the Control of Imported Publications Act 1958 (Act 63). In general, the PPA regulates the ownership and use of printing presses as well as the publication and importation of printed materials, including documents, newspapers, books, periodicals, and other publications (Rachagan, 1993). Since then, the PPA, which is currently administered by the Ministry of Home Affairs (the Minister), has employed a rigid regulatory framework to control the print media by adopting two levels of restraints, namely, media content and media access (George, 2003). Regarding the regulation of media content, sections 4, 7, and 8A of the PPA empower the Minister to restrain the printing and circulation of 'unlawful, ' 'undesirable,' and 'malicious' publications. Unfortunately, these provisions seem to have conferred too much authority on the Minister and such power may potentially be misused to suppress dissent and criticisms of the ruling government (Ismail Nawang, 2015). This could best be illustrated by the infamous criminal charge brought against Irene Fernandez, a social activist at Tenaganita, for publishing a memorandum that revealed the ill-treatment of migrant workers at a detention camp which was dubiously regarded as an offence under section 8A (Kong, 2008).

As for control via media access, the PPA requires the possession of a valid printing press permit and publication licence before any person can print, publish, and circulate any materials to the public. Moreover, the power to grant, refuse, revoke or suspend any permit or licence is vested exclusively in the Minister, and his decision shall be final. ${ }^{6}$ The constitutionality of the Minister's power has been challenged in the case of Persatuan Aliran Kesedaran Negara

6 Section 13A(1) of the PPA stipulates that "Any decision of the Minister to refuse to grant or to revoke or to suspend a licence or permit shall be final." 
v. Minister of Home Affairs. ${ }^{7}$ The application by the applicant to publish its monthly magazine, Aliran, in the Malay language was rejected without any specific reason. In the first instance, the High Court ruled that the Minister did not have any good reason to reject the application. However, the decision was reversed on appeal as the Supreme Court decided that the Minister had not "exercised his discretion wrongfully, unfairly, dishonestly or in bad faith". ${ }^{8}$ Thus, the Minister's decision was final, and his discretion cannot be challenged in court. Consequently, it is pertinent to scrutinise the licensing system under the PPA in detail.

\section{The Licensing System under the PPA}

The essence of the regulatory framework governing print media under the PPA is the imposition of prior constraints via printing press licences and publication permits. Section 3(1) of the PPA states that, "No person shall keep for use or use a printing press unless he has been granted a licence under subsection (3)". The provision effectively requires all proprietors and operators ${ }^{9}$ of any printing presses ${ }^{10}$ (i.e., any machines or devices that can generate at least 1,000 impressions within one hour) to procure and possess valid printing press licences before they can lawfully own and start printing any materials using such machines. At first glance, the licensing scheme seems to cover all types of printing machines. However, section 3(8) of the PPA expressly excludes certain printing equipment from its ambit, such as word processors, offset printers, microcomputers, and photocopying machines. ${ }^{11}$ Therefore, only those printing machines that have met 7 [1988] 1 MLJ 440.

8 Minister of Home Affairs v. Persatuan Aliran Kesedaran Negara [1990] 1 MLJ 351.

9 Section 2 of the PPA defines the word 'person' in section 3 to include "a body corporate or unincorporated'. Thus, the requirement applies to all natural and artificial persons such as companies and corporate entities.

10 The phrase 'printing press' is defined in section 3(2) of the PPA as "the machine, equipment or article for printing, copying or reproducing any document described in Schedule I", while Schedule I stipulates the lists of machines as follows: "Letterpress, Lithography, Gravure, Intaglio or any other process of printing capable of printing at a rate of 1,000 impressions per hour or more."

11 Section 3(8) of the PPA states that "Nothing in this section shall extend to the impression of any engraving or to the printing of any visiting or business card, billhead or letter heading, or to any letter, memorandum 
the prescribed criteria as stipulated in section 3(1) and Schedule I of the PPA need to be licensed by the Minister.

Application for printing press licences under the PPA is subject to the Printing Presses and Publications (Licences and Permits) Rules 1984 (PPR). ${ }^{12}$ The PPR requires an application to be made in the prescribed form ${ }^{13}$ and to fulfil all conditions as may be endorsed on the licence by the Minister. ${ }^{14}$ It is important to highlight that one of the standard conditions of the licence restricts the use of the printing machines from printing any publication which is "prejudicial to or is likely to be prejudicial to public order, morality, security, the relationship with any foreign country or government, or which is likely to be contrary to any law or is otherwise prejudicial to or is likely to be prejudicial to the public interest or the national interest." 15 It is observed that such conditions emulates almost the same statutory control on the publication of 'undesirable' content which is "prejudicial to or likely to be prejudicial to public order, morality, security, or which is likely to alarm public opinion, or which is or is likely to be contrary to any law or is otherwise prejudicial to or is likely to be prejudicial to public interest or national interest." By virtue of section 7 of the PPA, the Minister is empowered to prohibit not only the printing of materials that are regarded as 'undesirable' but also the "importation, production, reproduction, publishing, sale, issue, circulation, distribution or possession" of such documents.

In addition to the aforesaid prohibition on the publication of undesirable content, printing machine owners are also bound by section 4 of the PPA which among other things forbids the printing

or document whatsoever, typed, printed or reproduced in the ordinary course of business, not being a printing or publishing business, or for any other lawful object or purpose."

12 The PPR were made by the Minister by virtue of section 26 of the PPA.

13 Rule 2 of the PPR states that "Every application for a licence or permit under the Act shall be made in duplicate in the form prescribed by the Minister."

14 Rule 3 of the PPR stipulates that "The licence and permit granted under the Act shall be in the forms appearing in the First Schedule containing such conditions as are specified therein and such further conditions as may be endorsed therein by the Minister."

15 Rule 4 of the PPR. 
of any publications which are "obscene or otherwise against public decency," incite "violence against persons or property," or promote "feelings of ill will, hostility, enmity, hatred, disharmony or disunity" in the country. Further, the print media are restrained from publishing false news, as section 8A of the PPA expressly provides that it is an offence for any printer, publisher, editor, and the writer to publish false news maliciously. In this regard, it is submitted that these statutory controls indirectly signify the government's recognition of the prevalent persona of the print media and its strong emphasis on controlling the dissemination of illicit materials to members of the public. Nonetheless, the only caveat is that these restrictions, if not properly exercised by the authorities, may be exploited to censure constructive criticisms and conflicting points of view about the ruling government.

Apart from controlling the proprietorship and use of the printing presses via the licensing requirements, section 5(1) of the PPA mandates newspaper publishers to acquire publication permits from the Ministry of Home Affairs before they can print, publish, sell, circulate or distribute any newspapers printed in Malaysia or Singapore. It is thus critical to have a complete grasp of the term 'newspaper' as explicitly stipulated in the PPA. The term is defined in section 2 of the PPA to cover any "magazine, comic, periodical or publication containing news, reports of occurrences or any comments in relation to such news, or to any other matter of public interest, irrespective of whether the publication is free or for sale." It is apparent that the statutory interpretation gives a very broad scope for the term 'newspaper' so as to render almost all publishers of any 'publication' that disseminates information to be statutorily mandated to procure publication permits. As to when a publication takes place, Mahadev Shankar J in the case of Ling Wah Press Sdn Bhd v. Pustaka Utama Pelajaran Sdn Bhd \& 3 Ors $^{16}$ ruled that "A document only became a publication when it was published i.e. made available for public consumption."

Regarding the term 'publication,' it is outlined in section 2 of the PPA to comprise "a document, newspaper, book, periodical, all written or printed matter, anything containing visible representation or suggesting words or ideas, and audio recording." Nonetheless, 16 [1994] 3 CLJ 346 
the inclusion of 'audio recording' within such interpretation may cause confusion to the owners of online news portals or other online publishers. With regard to 'audio recording', the phrase is statutorily interpreted as "any material on which is recorded a recording of a human voice or of instrumental music or other sounds and includes phonograph records, tapes and laser disc." Since online news portals may upload and publish audio recordings on their platforms, an issue arises as to whether they are also required to possess publication permits from the Minister before publishing such recordings on the Internet. Further, unlike publications by the Federal or State government as well as publications by any statutory bodies, online publications are not expressly exempted in section 25 of the PPA. This is in total contrast to the application for printing press licence which is confined only to the owners of printing machines that have fulfilled all of the statutory requirements in section 3 and Schedule I of the PPA and is therefore not applicable to online news portals.

The ambiguity regarding the publication permit requirements for online newspapers and other online publishers may hinder them from at least disseminating audio recordings to the public. Should the publication permit be imposed on them, their failure to comply with the statutory requirements will constitute an offence under section 5(2) of the PPA which is punishable upon conviction with a jail term not exceeding three years or to a maximum penalty of RM20,000 or to both. For the avoidance of doubt, it was argued that the words 'audio recording' should ideally be expunged from the definition of 'publication' so as to warrant clarity and avoid future conflicts with other laws (Ismail Nawang \& Mustaffa, 2017). Further, it should be noted that the provisions of the PPA have been specifically formulated to cater to traditional print media, whereas audio-visual services should rightly be subjected to the provisions of the CMA.

Apart from complying with the requirements of sections 4, 7, and $8 \mathrm{~A}$ of the PPA on content regulations, any applications for printing press licences or publication permits are required by section 10 of the PPA to be furnished with a prescribed deposit as security with the government. The amount of deposit to be paid varies from one publication to another, as stated in related rules such as the Printing Presses and Publications (Importation of Publications) (Deposit) 
Rules, 1985, which ranges from RM6,000 to RM90,000. In addition, all applicants must pay a certain amount of fees as stipulated in rule 4 of the Printing Presses and Publications (Licences and Permits) Rules, 1984, and the current rates of fees published on the website of the Ministry of Home Affairs range from RM50 to RM3,000.

With regard to the potential application of the aforesaid licensing requirements of online news portals, a prominent legal scholar, Buang (2015) argued that the statutory requirements of printing press licence and publication permit cannot be applied to blogs and social networking sites. It is therefore submitted that though there is a slight possibility for online news portals or other online publishers that publish audio recordings to be required to comply with the regulatory regime of the PPA, the governance and control of the new media including online news portals should ideally be subjected to the provisions of the CMA. Thus, it is material to analyse the provisions of the CMA in determining the potential application of the statute to online news portals.

\section{COMMUNICATIONS AND MULTIMEDIA ACT 1998 (CMA)}

The CMA was passed by the Parliament a year after the launch of the first set of cyber laws comprising the Computer Crimes Act 1997, the Digital Signature Act 1997, and the Telemedicine Act 1997. The CMA was concurrently passed with the Malaysian Communications and Multimedia Commission Act 1998 (MCMCA), which statutorily empowers the establishment of a new regulatory body, namely the Malaysian Communications and Multimedia Commission (MCMC). The MCMC has been entrusted to regulate and supervise the emerging communications and multimedia industry. All of these laws were primarily enacted to accommodate the development of the special brainchild of the fourth Prime Minister, known as the Multimedia Super Corridor (MSC) Malaysia. The MSC Malaysia is a gigantic project which was launched in 1996 as part of the government's efforts to accelerate the growth of the nation's Digital Economy (MSC Malaysia, 2019).

In principle, the CMA was specifically enacted to accommodate the convergence of the previously stand-alone industries, namely 
broadcasting, telecommunications, and information technology. This is explicitly stated in the preamble of the CMA which asserts that the statute is "to provide for and to regulate the converging communications and multimedia industries, and for incidental matters." Prior to the enactment of the CMA, the broadcasting industry was regulated by the Broadcasting Act 1988 (BA). The BA was legislated to empower the government to control the ownership of private commercial stations, monitor broadcasting activities, and regulate programme content broadcasted by those stations via the licensing mechanism. ${ }^{17}$ Meanwhile, the telecommunications industry was previously controlled by the Telecommunications Act 1950.

As for the information technology industry, it was at first considerably uncontrolled during the country's initial venture into the Internet in the early 1990s (Hussein, 2000). In 1992, Joint Advanced Research Integrated Networking (JARING) was the only Internet Service Provider (ISP) in Malaysia, and it was operated by the Malaysian Institute of Microelectronic Systems (MIMOS), which was back then a unit under the Prime Minister's Department (MIMOS, n.d.). Thus, JARING was not required to possess any licence because the government could directly control the information technology industry without the need to have specific laws. This situation has since altered after the issuance of the second ISP licence in 1996 to a private company, Telekom Malaysia Berhad (now known as TM) (Lee, 2002). Two years later, five other ISP licences were issued to other private companies, namely TIME, Maxis, Mutiara, Celcom, and Prismanet (Lee, 2002). In line with this development, the government passed the CMA in 1998 with the primary objective of supervising and regulating the three previously different industries which have converged and clustered as a "new communications and multimedia industry.'

With the coming into operation of the CMA, the converging communications and multimedia industries in the country together with other services that fall within the realm of the Postal Services Act 1991 and the Digital Signature Act 1997 are now governed by a single regulatory framework under the CMA and supervised by the MCMC. This has resulted in the MCMC, (which was officially established on 1 November 1998 pursuant to the MCMCA), becoming a 'super regulator' "with powers to supervise and regulate 17 Section 4 of the Broadcasting Act 1998. 
the communications and multimedia activities in Malaysia, and to enforce the communications and multimedia laws of Malaysia, and for related matters." 18

\section{The Licensing System under the CMA}

The regulatory framework established by the CMA has introduced a new licensing system for the communications and multimedia industry. The CMA adopts a non-specific set of provisions based on generic definitions of market and service activities, including 'network facilities', 'network services', 'application services', and 'content application services.' These phrases are exclusively framed to be technology and service neutral to cover possibly all aspects of technological convergence and future changes. ${ }^{19}$ It has been argued that the use of such phrases denotes the language of new media and market convergence (Kitley, 2001).

As regards the licensing requirements, the statute only acknowledges and mandates four types of activities to be licensed, which are either individual or class licence under the CMA. ${ }^{20}$ Section 126 of the CMA prohibits the providers of network facilities, network services, and applications services from possessing the facilities and providing related services without procuring a valid licence. Meanwhile, section 205 of the CMA requires the providers of content applications services to hold a valid individual or class licence before providing their services to the public.

The term 'network facilities provider' is interpreted in section 6 of the CMA as "a person who owns or provides any network facilities." In relation to the licensing system, the Licensing Guidebook of the MCMC may be referred to as it provides guidance to all related parties in understanding the requirements under the CMA. The Licensing Guidebook provides that network facilities refers to "infrastructures

18 Preamble to the MCMCA.

19 Clause 1.2 of the MCMC's Licensing Guidebook.

20 Section 6 of the CMA defines an individual licence as "a licence for a specified person to conduct a specified activity and may include conditions to which the conduct of that activity shall be subject." Meanwhile, a class licence means "a licence for any or all persons to conduct a specified activity and may include conditions to which the conduct of that activity shall be subject." 
such as cables, towers, satellite earth stations, broadband fibre optic cables, telecommunications lines and exchanges, radio communications transmission equipment, mobile communications base stations and broadcasting transmission towers and equipment." As for 'network service provider,' the phrase is defined in the same section of the CMA as "a person who provides network services." The Licensing Guidebook provides further elaboration on the term as it refers to the person who "provides the basic connectivity and bandwidth to support a variety of applications."

Pertaining to 'applications service provider,' the phrase is statutorily interpreted as "a person who provides an applications service" and such service is interpreted in the same section as "a service provided by means of, but not solely by means of, one or more network services." The Licensing Guidebook provides that an applications service provider offers particular functions such as voice services, data services, Internet access, and electronic commerce. Regarding 'content applications services,' section 6 of the CMA interprets the phrase as "an applications service which provides content," whereas the word 'content' refers to "any sound, text, still picture, moving picture or other audio-visual representation, tactile representation or any combination of the preceding which is capable of being created, manipulated, stored, retrieved or communicated electronically." It is also stipulated in the Licensing Guidebook that content applications service providers represent a special subset of applications service providers such as television and radio broadcast services as well as other services including online publishing and the provision of information services.

A close scrutiny of the aforesaid licensable activities reveals that the operators of online news portals or owners of other webbased publications do not come within the meaning of network facilities providers, network service providers, or applications service providers. Therefore, it is obvious they will not be obliged to procure such licences under the CMA. Nonetheless, section 6 of the CMA may render the inclusion of online news portals or online publications within the range of content applications services. The licensing requirements in the CMA must be read together with other subsidiary legislations or regulations that have been made by the Minister. Order 6 of the Communications and Multimedia 
(Licensing) (Exemption) Order 2000 states that "a person who provides any Internet content applications services is exempt from holding an individual licence or registering under a class under the Act." At the same time, Order 2 defines the phrase 'Internet content applications services' as "a content applications service which is delivered by means of the Internet."

Therefore, since online news portals or other web-based publication channels disseminate content into cyberspace via the Internet, the providers or operators of these online platforms are essentially at liberty to publish any information without the requirement to be in possession of either individual or class licences under the CMA. The exemption from holding valid licences as providers of content applications services arguably seems to be in line with the government guarantee of no censorship of the Internet, which is contained in the CMA and the BoGs. Hence, it is necessary to elaborate on the legal implications of the no censorship guarantee of online news portals.

\section{The Guarantee of No Censorship of the Internet}

The guarantee of no censorship of the Internet was first declared in 1997 by the fourth Prime Minister of Malaysia, Tun Dr Mahathir Mohamad, during the promotion of the MSC Malaysia to a group of foreign investors in California, United States (Steele, 2007). Subsequently, the no censorship of the Internet policy was integrated into the BoGs and the CMA in 1998. The no censorship guarantee is part of the country's selling points to attract investments in the MSC Malaysia (George, 2006). At the same time, the policy aims to rival investments to Singapore and other Southeast Asian countries (Davidson, 1998). Even though the number of reported cases of online perils has grown continuously (Hamidah Atan, 2009), the government's commitment to the guarantee of not censoring the Internet remains until today (Dass, 2009). As such, it is argued that the perceived economic value of the Internet has prompted the government to not only embrace the no censorship policy but also to set aside restrictive legal mechanisms which have been enforced on traditional media, from being extended to the online platforms.

Nonetheless, the existence of the no censorship promise of the Internet has resulted in an unsubstantiated perception that the Internet in the 
country should be free from any statutory or legislative controls (Ramachandran, 2008). Such belief is baseless and unfounded as the explanation accompanying the BoG 7 clearly states that there will be no differential treatment between the physical world and online environment as what is illegal offline will also be illegal online. ${ }^{21}$ Further, section 3(3) of the CMA does not preclude the application of existing laws such as defamation, sedition, or even the provisions of the CMA on online materials. For that reason, it is evidently erroneous to assume that the Internet is a lawless space merely due to the existence of the no censorship promise since all existing laws are equally applicable to the Internet. Apart from that, it should be noted that all Internet users in the country cannot easily shield their true identities by using pseudonyms or anonymous accounts with the coming into operation of section 114A of the Evidence Act 1950 (Ismail Nawang, 2017).

\section{FINDINGS}

Detailed analysis of the legal framework under the PPA regulating traditional print media in the country shows that it is improbable for online news portals or other online publications in Malaysia to be governed by the statutory requirements of the PPA. This is predominantly apparent since the provisions of the PPA were drafted to primarily regulate print media, and it was passed long before the convergence era in the late 1990s.

Regarding the licensing system under the CMA, which has been specifically enacted for the convergence of new technologies, section 6 of the CMA clearly renders online publications, including online news portals, to be within the remit of content applications services. Nonetheless, operators of online news portals or other online publishers are not obliged to apply for any licences since they are explicitly exempted by the Communications and Multimedia (Licensing) (Exemption) Order 2000. Thus, online news portals or other web-based publications are at liberty to disseminate any online materials without the need to acquire any prior licences or permits,

21 For a detailed explanation on MSC Malaysia Bill of Guarantees (BoGs) see <https://www.mida.gov.my/env3/uploads/IncentivesCompilation/ MDEC/2013/AppII.pdf $>$ accessed on 12 January 2020. 
and this is arguably congruent with the guarantee of no censorship of the Internet.

Nevertheless, it is imperative to highlight that the lack of licensing requirements does not entirely liberate the operators of online news portals or owners of other web-based platforms from any legal obligations. Although online news portals are at present excluded from acquiring content applications service licences, they are still bound by a myriad of post-publication laws on content regulations under the CMA or other prevailing statutes such as the Defamation Act 1957, the Sedition Act 1948, the Official Secrets Act 1972, and many others. Further, there is no guarantee that the exemption order will be kept in perpetuity as the Minister is statutorily empowered to vary or even repeal such order in the future. This is best illustrated by the press statement of the former Minister, who was reported to have commented on the proposal to regulate online news portals by saying that the government was looking to introduce amendments to the CMA and MCMCA (Carvalho et al., 2015). Thus, the current position may change in the future if the need arises to regulate online publications.

\section{CONCLUSION AND RECOMMENDATIONS}

To sum up, apart from the application of post-publication laws (either civil or criminal laws), it is submitted that leaving online news portals not bound by any specific legal regime, such as the PPA that governs print media, is highly undesirable because these new media may potentially be exploited to propagate hatred and disseminate lies in cyberspace. Further, this exemption is unfair to online news portals that are connected to print media as the latter at present are subjected to a strict regulatory regime under the PPA. Apart from that, there were reported incidents of reporters from Malaysiakini (one of the earliest online news portals) and web radio, RadiqRadio being denied access to the press gallery in the Parliament on the sole grounds that they were not endorsed by the Information Ministry (Halim \& Salim, 2005). As such, it is argued that online news portals in Malaysia should not be treated differently from traditional print media and thus should then be subjected to certain specific regulatory control. 
The current situation in the UK could be referred to as all offline and online presses, including online news portals are subject to the same self-regulatory regime controlled by the Independent Press Standards Organisation (IPSO). The IPSO's responsibility, which is explicitly specified in the Articles of Association (AOA) and Regulations, provides that the IPSO shall administer "editorial content included in a printed newspaper or magazine" and "editorial content on electronic services operated by Regulated Entities such as websites and apps, including text, pictures, video, audio/visual and interactive content". ${ }^{22}$ Hence, any materials issued by member publishers, whether in print or online, shall be bound by the IPSO's regulations. However, there are certain exemptions to the IPSO's remit, which is spelt out in Article 7.3 of the IPSO's AOA, and these include complaints about 'user-generated content' posted on the websites of member publishers that has yet to be reviewed or moderated by them. In addition, any grouses relating to online materials that are not displayed on the websites of member publishers will also be outside of the IPSO's remit. ${ }^{23}$

The IPSO's remit is, to a large extent, commensurate with the ambit of its antecedent, the Press Complaints Commission (PCC). At the early stage of its operation, the remit of the PCC only applied to the editorial content of the print media. The remit was expanded in 1997 to include electronic editions of the press which reproduced the printed versions. In 1999, the remit of the PCC was again altered to cover freestanding or electronic issues as long as they were primarily established in the UK. Thus, it is apparent that the IPSO's remit is substantially identical to that of the PCC as the IPSO is authorised to resolve complaints on publications edited by member publishers notwithstanding print publications or electronic forms. It is therefore submitted that the IPSO, which was inaugurated by the print industry, has accorded certainty and uniformity to all of the media practitioners in the UK, and the operation and remit of this self-regulatory body could be referred to and perhaps replicated by the Malaysian government in addressing the different regulatory regimes that are currently imposed on print and online media in the country.

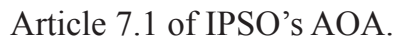




\section{ACKNOWLEDGEMENTS}

This research is funded by the Ministry of Education Malaysia through the Fundamental Research Grant Scheme (FRGS) FRGS/1/2019/SSI10/UNISZA/02/2.

\section{REFERENCES}

Aaron D Davidson. (1998). I want my censored mtv: Malaysia's censorship regime collides with the economic realities of the twenty-first century. Vanderbilt Journal of Transnational Law, 31, 97. http://heinonline.org/HOL/Page?handle=hein. journals $/$ vant131\&id=111\&div $=\&$ collection=journals

Ahmad, Z. A., \& Buyong, M. (2017). Content analysis of online news portal: Issues and challenges. Journal of Social Sciences and Humanities, 14(6), 164-174.

Alivi, M. A., Ghazali, A. H. A., Tamam, E., \& Osman, M. N. (2018). A review of new media in Malaysia: Issues affecting society. International Journal of Academic Research in Business and Social Sciences, 8(2). https://doi.org/10.6007/IJARBSS/v8i2/3849

AP News. (1986). Malaysia Bans Asian Wall Street Journal for Three Months. AP NEWS. https://apnews.com/9370327765f 7075afc1063a993f36b61

Ariffin, M. Y. M., \& Jaafar, N. I. (2009). Online newspaper in Malaysia: A preliminary study. Malaysian Journal of Media Studies, 11(1), 83-94. http://citeseerx.ist.psu.edu/viewdoc/do wnload?doi=10.1.1.672.8057\&rep=rep1\&type $=$ pdf

Azlan, A. A., A., Rahim, S., Hassan Basri, F. K., \& Hasim, M. S. (2012). Malaysian newspaper discourse and citizen participation. Asian Social Science, 8(5). https://doi. org/10.5539/ass.v8n5p116

Blackman, C. R. (1998). Convergence between telecommunications and other media: How should regulation adapt? Telecommunications Policy, 22(3), 163-170. https://doi. org/10.1016/S0308-5961(98)00003-2

Buang, S. (2015, September 17). Our media law limitations. New Straits Times. https://www.nst.com.my/news/2015/09/ourmedia-law-limitations 
Carvalho, M., Sivanandam, H., \& Ghazali, R. (2015, August 6). Govt Considers Registering Portals. The Star Online. https://www. thestar.com.my/News/Nation/2015/08/06/Govt-considersregistering-portals-Minister-Proposed-amendments-to-cyberlaws-will-strengthen-social

Chinnasamy, S. (2018). New Media Political Engagement and Participation in Malaysia. Routledge.

Dass, M. J. (2009, September 8). PM reaffirms censorship-free Internet. The Sun, 1.

Erlindson, M. (1995, April). Online newspapers: The newspaper industry's dive into Cyberspace. https://scholar.google.com/ scholar?hl=en\&as_sdt $=0 \% 2 \mathrm{C} 5 \& \mathrm{q}=$ Online + Newspapers $\% 3$ $\mathrm{A}+$ The + Newspaper+Industry $\% \mathrm{E} 2 \% 80 \% 99 \mathrm{~s}+$ Dive + into $+\mathrm{Cy}$ berspace. + paper + presented + at + the + University + of + Western + Ontario $\% 2 \mathrm{C}+$ April\&btnG $=$

Freeman, K. S. (2013). News consumption behavior of young adults in Malaysia. International Journal of Social Science and Humanity, 121-124. http://www.ijssh.org/index.php? $\mathrm{m}=\mathrm{cont}$ ent $\& \mathrm{c}=$ index $\& \mathrm{a}=$ show $\&$ catid $=37 \& \mathrm{id}=478$

George, C. (2003). The Internet and the narrow tailoring dilemma for "Asian" democracies. The Communication Review, 6(3), 247-268. https://doi.org/10.1080/10714420390226270.002

George, C. (2005). The Internet's political impact and the penetration/ participation paradox in Malaysia and Singapore. Media, Culture \& Society, 27(6), 903-920.

George, C. (2006). Contentious journalism and the Internet: Towards democratic discourse in Malaysia and Singapore (Rev. ed.). University of Washington Press.

Halim, Z. A., \& Salim, M. R. (2005). The media system and cooperative regulatory systems in the media sector of Malaysia. Hans-Bredow-Institute for Media Studies.

Hamidah Atan. (2009, September 8). No Internet censorship despite cyber threats, says Najib. The New Straits Times, 1-2.

Hussein, S. Mohd. (2000). The Malaysian Communications and Multimedia Act 1998-Its implications on the information technology (IT) industry. Information \& Communications Technology Law, 9(1), 79-88. http://www.informaworld. com/10.1080/136008300111619

Ismail Nawang, N. (2014). Greater freedom in the cyberspace? An analysis of the regulatory regime of the Internet in Malaysia. $5(4), 5$. 
Ismail Nawang, N. (2015). Political blogs and freedom of expression: A comparative study of Malaysia and the United Kingdom [University of Edinburgh]. https://era.ed.ac.uk/ handle/1842/10658

Ismail Nawang, N. (2017). Combating anonymous offenders in the cyberspace: An overview of the legal approach in Malaysia. 2017 2nd International Conference on Anti-Cyber Crimes (ICACC), 13-18. https://doi.org/10.1109/AntiCybercrime.2017.7905255

Ismail Nawang, N., \& Mustaffa, A. (2017). Online news portals in Malaysia: Should they be subjected to the existing traditional media laws? World Applied Sciences Journal, 35(9), 17181722. https://doi.org/10.5829/idosi.wasj.2017.1718.1722

Joo Chung, C., Kim, H., \& Hyun Kim, J. (2010). An anatomy of the credibility of online newspapers. Online Information Review, 34(5), 669-685. http://www.emeraldinsight.com/ doi/10.1108/14684521011084564

Kasim, A., \& Mohd Sani, M. A. (2016). The 2013 general elections in Malaysia: An analysis of online news portals. Kasetsart Journal of Social Sciences, 37(2), 119-125. https://linkinghub. elsevier.com/retrieve/pii/S2452315116300108

Kim, W. L. (1998). Malaysia: Ownership as control. Development Dialogue, 2, 24.

Kitley, P. (2001). Subject to what?: A comparative analysis of recent approaches to regulating television and broadcasting in Indonesia and Malaysia. Inter-Asia Cultural Studies, 2(3), 503-514.

Kong, L. (2008). Activist Irene Fernandez acquitted (updated). The Star Online. https://www.thestar.com.my/news/ nation/2008/11/24/activist-irene-fernandez-acquittedupdated

Lee, C. (2002). Telecommunications reforms in Malaysia. Annals of Public and Cooperative Economics, 73(4), 521-540. https:// doi.org/10.1111/1467-8292.00203

Malaysian communications and multimedia commission (MCMC). (2019). Internet Users Survey 2018. https://www.mcmc.gov. my/skmmgovmy/media/General/pdf/Internet-Users-Survey2018.pdf

Manning, M. (1983). Rights, freedoms and the courts: A practical analysis of the Constitution Act, 1982. Emond-Montgomery. 
MIMOS. (n.d.). Milestones - MIMOS Berhad. Retrieved 18 January 2020, from http://www.mimos.my/about-us/the-company/ milestones/

MSC Malaysia. (2019, June 12). MDEC. https://mdec.my/what-weoffer/msc-malaysia/

Mustaffa, N., Ibrahim, F., Samani, M. C., \& Rahim, M. H. A. (2010). Persepsi khalayak terhadap kredibiliti media di Malaysia. Jurnal e-Bangi, 5(2), 153-160.

Nain, Z. (2000). Globalized theories and national controls: The state, the market and the Malaysian media. In M.-J. Park \& J. Curran (Eds.), De-Westernizing Media Studies (pp. 139-153). Routledge.

Nain, Z. (2018). Digital News Report 2018-Malaysia (pp. 131-132). http://media.digitalnewsreport.org/wp-content/ uploads/2018/06/digital-news-report-2018.pdf

Netto, A. (2002). Media freedom in Malaysia: The challenge facing civil society. Media Asia, 29(1), 17-23. http://www. tandfonline.com/doi/full/10.1080/01296612.2002.11726658

Newman, N., Fletcher, R., Kalogeropoulos, A., \& Nielsen, R. K. (2019). Reuters Institute Digital News Report 2019 (p. 156). https://reutersinstitute.politics.ox.ac.uk/sites/default/files/ inline-files/DNR_2019_FINAL.pdf

Rachagan, S. S. (1993). Law and the electoral process in Malaysia. University of Malaya Press.

Ramachandran, S. (2008, August 31). Cyber Crimes: The net is not in a legal vacuum. New Sunday Times. http://www. malaysianbar.org.my/information_technology_and cyberlaws_2005_2007/cyber_crimes_the_net_is_not_in_a legal vacuum.html

Russo, M. (2006). Are bloggers representatives of the new media under the freedom information act? Columbia Journal of Law and Social Problems, 40, 225.

Sani, M. A. M. (2005). Media freedom in Malaysia. Journal of Contemporary Asia, 35(3), 341-367. http://www.tandfonline. com/doi/abs/10.1080/00472330580000201

Shukry, A. (2015, July 27). Malaysia's brief, rich history of suspending newspapers. The Edge Markets. http://www. theedgemarkets.com/article/malaysia\%E2\%80\%99s-briefrich-history-suspending-newspapers

Steele, J. (2007). Malaysia's untethered net. Foreign Policy, 161, $86-88$. 
Tiung, L. K., Meri, A., Nayan, L. M., \& Othman, S. S. (2016). Kegunaan dan kepuasan portal berita dalam kalangan belia Malaysia. Jurnal Komunikasi: Malaysian Journal of Communication, 32(2), 790-816.

Tong, Y. S. (2004). Malaysiakini: Threading a tightrope of political pressure and market factors. In S. Gan, J. Gomez, \& U. Johannen (Eds.), Asian Cyberactivism: Freedom of Expression and Media Censorship (pp. 270-317). Friedrich Naumann Foundation.

Zweigert, K., \& Kötz, H. (1987). Introduction to Comparative Law (2nd Rev. ed.). Clarendon Press. 